\title{
IMPLEMENTASI KEUANGAN DESA BERDASARKAN UNDANG-UNDANG PEMERINTAHAN DAERAH
}

\author{
Betha Rahmasari \\ Universitas Muhammadiyah Metro \\ umdosen@gmail.com
}

\begin{abstract}
Desa merupakan kesatuan masyarakat hukum yang memiliki kewenangan untuk mengatur dan mengurus kepentingan masyarakat setempat berdasarkan asal usul dan adat istiadat setempat yang diakui dalam sistem Pemerintahan Nasional dan berada di daerah Kabupaten. Desa berfungsi sebagai ujung tombak di dalam melaksanakan pembangunan disegala bidang baik di bidang Pemerintahan, pembangunan, maupun kemasyarakatan maupun tugas-tugas pembantuan yang merupakan pembangunan integral yang tidak dapat dipisahkan satu sama lainnya yang meliputi kehidupan dan penghidupan masyarakat.

Pembangunan desa mempunyai peranan yang sangat penting dan strategis dalam rangka Pembangunan Nasional dan Pembangunan Daerah, karena di dalamnya terkandung unsur pemerataan pembangunan dan hasil-hasilnya. Selain itu, pembangunan desa dapat menyentuh secara langsung kepentingan sebagian besar masyarakat yang bermukim di perdesaan dalam rangka upaya meningkatkan kesejahteraan mereka. Dalam pembangunan desa pemerintahan desa berkedudukan sebagai subsistem dari sistem penyelenggaraan pemerintahan di Indonesia, sehingga desa memiliki kewenangan, tugas dan kewajiban untuk mengatur dan mengurus kepentingan masyarakatnya sendiri. Masyarakat internasional sering menyebut pemerintah desa dengan istilah "local government".

Tata kelola penyelenggaraan pemerintahan yang baik dalam suatu Negara merupakan suatu kebutuhan yang tak terelakkan. Sejalan dengan dikeluarkannya Undang-Undang Nomor 6 Tahun 2014 Tentang Desa, perlu mendapat perhatian yang serius mengingat selama ini pemerintahan desa diatur dengan Undang-Undang Nomor 32 Tahun 2004 Jo Undang-Undang Nomor 23 Tahun 2014 Tentang Pemerintahan Daerah.
\end{abstract}

Kata kunci : Desa, Keuangan Desa, Pemerintahan Daerah 


\begin{abstract}
The village is a legal community that has the authority to organize and manage the interests of the local community based on local origins and customs that are recognized in the National Government system and located in the District. The village serves as the spearhead in carrying out development in all fields both in the field of Government, development, and society as well as tasks of assistance which is integral development that can not be separated from each other which includes life and livelihood of the community.

Rural development has a very important and strategic role in the framework of National Development and Regional Development, because it contains elements of equity of development and its results. In addition, village development can directly touch the interests of the majority of people who live in rural areas in order to improve their welfare. In the village village government development is located as a subsystem of the governance system in Indonesia, so that the village has the authority, duties and obligations to organize and manage the interests of its own community. The international community often calls the village government the term "local government".

Good governance governance in a State is an inevitable necessity. In line with the issuance of Law Number 6 Year 2014 About the Village, it needs serious attention considering that during this village government is regulated by Law Number 32 Year 2004 Jo Law Number 23 Year 2014 About Local Government.
\end{abstract}

Keywords: Village, Village Finance, Local Government

\title{
PENDAHULUAN
}

Perimbangan keuangan pusat-daerah kini telah menjadi ikon utama otonomi daerah dan sudah dipastikan dengan kebijakan negara melalui Undang-Undang Nomor 33 Tahun 2004. Ada dua alasan penting lahirnya kebijakan perimbangan keuangan pusat-daerah. Pertama, alasan teoretik yang berpijak pada anjuran desentralisasi. Desentralisasi menyatakan bahwa pembagian kekuasaan dan kewenangan dari pusat ke daerah harus diikuti dengan desentralisasi keuangan (fiskal) dalam bentuk pembagian keuangan kepada daerah dan memberi kekuasaan daerah untuk menggali sumber keuangan sendiri. Keuangan yang didesentralisasikan 
(decentralized budget) ke daerah digunakan untuk membiayai pelayanan publik dan pembangunan daerah yang sesuai dengan preferensi lokal.

Pada pasal 1 angka 5 Peraturan Pemerintah No. 72 Tahun 2005 menetapkan bahwa desa atau yang disebut dengan nama lain, seanjutkan disebut Desa, adalah kesatuan masyarakat hukum yang memiliki batas-batas wilayah yang berwenang untuk mengatur dan mengurus kepentingan masyarakat setempat, berdasarkan asal usul dan adat istiadat setempat yang diakui dalam sistem pemerintahan Negara Kesatuan Republik Indonesia. Berdasarkan pengertian tersebut sangat jelas bahwa undang-undang No. 32 Tahun 2004 memberikan dasar menuju self governing yaitu suatu komunitas yang mengatur dirinya sendiri, dengan pemahaman bahwa Desa memiliki kewenangan untuk mengatur dan mengurus kepentingan masyarakatnya sendiri sesuai kondisi dan social budaya setempat.

Desa merupakan kesatuan masyarakat hukum yang memiliki kewenangan untuk mengatur dan mengurus kepentingan masyarakat setempat berdasarkan asal usul dan adat istiadat setempat yang diakui dalam sistem Pemerintahan Nasional dan berada di daerah Kabupaten. Desa berfungsi sebagai ujung tombak di dalam melaksanakan pembangunan disegala bidang baik di bidang Pemerintahan, pembangunan, maupun kemasyarakatan maupun tugas-tugas pembantuan yang merupakan pembangunan integral yang tidak dapat dipisahkan satu sama lainnya yang meliputi kehidupan dan penghidupan masyarakat.

Pembangunan desa mempunyai peranan yang sangat penting dan strategis dalam rangka Pembangunan Nasional dan Pembangunan Daerah, karena di dalamnya terkandung unsur pemerataan pembangunan dan hasil-hasilnya. Selain itu, pembangunan desa dapat menyentuh secara langsung kepentingan sebagian besar 
masyarakat yang bermukim di perdesaan dalam rangka upaya meningkatkan kesejahteraan mereka. Dalam pembangunan desa pemerintahan desa berkedudukan sebagai subsistem dari sistem penyelenggaraan pemerintahan di Indonesia, sehingga desa memiliki kewenangan, tugas dan kewajiban untuk mengatur dan mengurus kepentingan masyarakatnya sendiri.

Masyarakat internasional sering menyebut pemerintah desa dengan istilah "local government". Peran pemerintahan ditingkat lokal/desa tersebut diakui memberi pengaruh pada pembangunan, sebagaimana pendapat dibawah ini:

"It is acknowledged that local governance constitutes the most critical level of governance where the momentum to sustain national development can be created. Local governance is a system of devolution of powers to the local authority to provide services of local nature. (Diakui bahwa pemerintahan local merupakan tingkat yang paling kritis dalam pemerintahan dimana momentum untuk melanjutkan pembangunan nasional dapat dilakukan. Tata pemerintahan lokal adalah sistem pengalihan kekuasaan kepada otoritas lokal untuk menyediakan layanan yang bersifat lokal)".

Dalam operasionalisasi Desa untuk mewujudkan otonomi yang diberikan kepada desa terdapat pembiayaan-pembiayaan, dimana pembiayaan tersebut memiliki hubungan dengan Alokasi Dana Desa, sehingga Pemerintah Daerah Kabupaten memberikan Alokasi Dana Desa kepada setiap Desa yang berada di wilayahnya. Hal ini tercantum pada Undang-Undang Nomor 6 Tahun 2014 tentang Desa yang menyebutkan bahwa keuangan desa adalah semua hak dan kewajiban Desa yang

\footnotetext{
${ }^{1}$ Abdur-rahman Olalekan Olayiwola. 2013. Local Governance and Public Goods: Some Lessons from the British Local Government System. European Journal of Bus iness and Social Sciences, Vol. 2, No.9 , pp 39-66, December 2013. Available at http://www.ejbss.com/recent.aspx
} 
dapat dinilai dengan uang serta segala sesuatu berupa uang dan barang yang berhubungan dengan pelaksanaan hak dan kewajiban desa yang menimbulkan pendapatan, belanja, pembiayaan dan pengelolaan keuangan desa. Alokasi Dana Desa diberikan oleh pemerintah Pusat yang diperoleh dari dana perimbangan APBN yang diterima oleh Kabupaten/Kota dalam Anggaran Pendapatan dan Belanja Daerah (APBD) setelah dikurangi Dana Alokasi Khusus (DAK) sebesar 10\%. Dana tersebut kemudian dapat digunakan untuk membiayai penyelenggaraan pemerintahan, pelaksanaan pembangunan, pembinaan kemasyarakatan, dan pemberdayaan masyarakat. Jumlah nominal yang akan diberikan kepada masing-masing desa akan berbeda tergantung dari georafis desa, jumlah penduduk, serta jumlah angka kematian. Alokasi dana sebesar $10 \%$ yang diterima oleh desa akan menyebabkan peningkatan terhadap pendapatan desa. ${ }^{2}$

Tata kelola penyelenggaraan pemerintahan yang baik dalam suatu Negara merupakan suatu kebutuhan yang tak terelakkan. Sejalan dengan dikeluarkannya Undang-Undang Nomor 6 Tahun 2014 Tentang Desa, perlu mendapat perhatian yang serius mengingat selama ini pemerintahan desa diatur dengan Undang-Undang Nomor 32 Tahun 2004 Jo Undang-Undang Nomor 23 Tahun 2014 Tentang Pemerintahan Daerah. Diaturnya desa dengan undang-undang tersendiri, memperlihatkan kemauan politik pemerintah untuk menjadikan desa sebagai basis pembangunan. Hal ini sejalan dengan visi dan misi Undang-undang tersebut, dimana Negara melindungi dan memperdayakan desa agar menjadi kuat dalam melaksanakan penyelenggarakan pemerintah, pembangunan dan kemasyarakatan menuju terciptanya masyarakat yang adil makmur dan sejahtera. Dalam Undang-Undang tersebut diatur tentang perlunya

\footnotetext{
${ }^{2}$ Widjaja HAW. 2003. Pemerintahan Desa/marga . Jakarta PT. Raja Grafindo Persada
} 
menerapkan kaidah-kaidah yang baik dalam menjalankan roda pemerintahan, termasuk di dalamnya kaidah-kaidah dalam bidang pengelolaan pemerintahan untuk mewujudkan tata kelola pemerintahan yang baik, yang didalamnya termasuk tata kelola keuangan pemerintahan pusat, daerah dan desa. Dalam rangka mewujudkan tata kelola keuangan pemerintahan yang baik itulah, pemerintah Republik Indonesia melakukan reformasi di bidang pengelolaan keuangan Negara dan daerah. Reformasi pengelolaan keuangan ini pada dasarnya dilatarbelakangi oleh masih digunakannya peraturan perundang-undangan peninggalan pemerintah kolonial. Walau kehendak menggantikan aturan bidang keuangan warisan telah lama dilakukan agar selaras dengan tuntutan zaman, baru pada tahun 2003 hal itu terwujud dengan terbitnya Undang-Undang Nomor 17 tahun 2003 tentang keuangan Negara. Hal itu senada dengan makin besarnya belanja Negara yang dikelola oleh pemerintah sehingga diperlukan suatu metode pengawasan yang memadai. Salah satu bentuknya adalah keterlibatan masyarakat/stakeholders. ${ }^{3}$

Sejauh ini keuangan desa didefinisikan sebagai semu hak dan kewajiban desa yang dapat dinilai dengan uang, serta segala sesuatu baik berupa uang maupun berupa barang yang dapat dijadikan milik desa berhubungan dengan pelaksanaan hak dan kewajiban tersebut. Keuangan desa pada dasrnya merupakan sub sistem dari keuangan Negara sebagaimana diatur dalam Undang-Undang Nomor 17 Tahun 2003, tentang keuangan Negara. Dalam penjelasan Undang-Undang tersebut dinyatakan bahwa ppendekatan yang digunakan dalam merumuskan keuangan Negara adalah dari sisi objek, subjek, proses, dan tujuan. Dari sisi objek, yang dimaksud dengan keuangan Negara meliputi semua hak dan kewajiban Negara yang dapat dinilai

\footnotetext{
${ }^{3}$ Chabib soleh, Heru Rochamansyah, 2010, Pengelolaan Keuangan Desa, fokusmedia
} 
dengan uang, termasuk kebijakn dan kegiatan dalam bidang fiskal, moneter dan pengelolaan kekayaan Negara yang dipisahkan, serta segala sesuatu baik berupa uang, maupun berupa barang yang dapat dijadikan milik Negara berhubungan dengan pelaksanaan hak dan kewajiban tersebut. ${ }^{4}$

\section{PEMBAHASAN}

Seiring dengan perkembangan politik, maka berdasarkan ketetapan Majelis Permusyawaratan Rakyat Republik Indonesia Nomor X/MPR/1998 tentang Pokokpokok reformasi pembangunan dalam rangka penyelamatan dan normalisasi kehidupan nasional sebagai Haluan Negara dan ketetapan MPR Republik Indonesia Nomor XV/MPR/1998 tentang penyelenggaraan otonomi daerah, pengaturan, pembagian dan pemanfaatan sumber daya nasional yang berkeadilan serta perimbangan keuangan pusat dan daerah dalam kerangka Negara Kesatuan Republik Indonesia, serta ketetapan Majelis Permusyawaratan Negara yang bersih dan bebas korupsi, Kolusi dan Nepotisme, ditetapkan Undang-undang No. 22 Tahun 1999 tentang Pemerintahan Daerah yang merupakn pengganti dari UU No. 5 Tahun 1974 tentang Pemerintahan di Daerah serta UU No. 5 Tahun 1979 tentang Pemerintahan Desa.

Undang-undang No. 22 Tahun 1999 tentang Pemerintaha Daerah, mengatur juga tentang Pemerintahan Desa, yaitu pada BAB XI dari pasal 93 sampai dengan Pasal 111. Banyak terdapat perubahan-perubahan yang mendasar bila dibandingkan dengan UU No. 5 Tahun 1979, antara lain pemerintahan desa buka lagi merupakan organisasi pemerintahan terendah di bawah camat, sehingga Kepala Desa tidak lagi bertanggung jawab kepada Bupati melalui Camat melainkan bertanggung jawab

\footnotetext{
${ }^{4}$ Bambang Trisantono. 2010. Pedoman Penyelenggaraan Pemerintahan Desa. Jakarta. Fokusmedia
} 
kepada rakyat melalui Badan Perwakilan Desa, yang berfungsi sebagai lembaga legislasi dan pengawasan dalam hal pelaksanaan peraturan desa, anggran pendapatan dan belanja desa, serta keputusan kepala desa. Lebih lanjut berdasarkan pasal 111 ditetapkan Peraturan Pemerintah No. 76 Tahun 2001 tentang Pedoman Umum Pengaturan Mengenai desa. ${ }^{5}$

Kemudian, berdasarkan pertimbangan bahwa undang-undang nomor 22 tahun 1999 tentang pemerintahan daerah dengan seluruh peraturan pelaksananya ternyata tidak sesuai dengan perkembangan keadaan, ketatanegaraan, dan tuntuttan penyelenggaraan otonomi daerah, maka UU No. 22 Tahun 1999 ini pun direvisi dan diganti dengan diterbitkannya Undang-undang No. 32 Tahun 2004.

Dalam Undang-undang No. 32 Tahun 2004 pengaturan mengenai Desa terdapat pada BAB XI pasal 200 sampai dengan Pasal 216. Sebagai tindak lanjut dari ketentuan [asal 216, ditetapkanlah Peraturan Pemerintah No. 72 Tahun 2005 Tentang Desa yang merupakan pedoman dalam penyelenggaraan pemerintahan Desa.

Pengertian keuangan desa menurut Undang-undang No. 32 Tahun 2004 Pasal 212 ayat (1) jo’ Permendagri No. 37 Tahun 2007 Pasal 1 angka (1) bahwa keuangan desa adalah semua hak dan kewajiban dalam rangka penyelenggara pemerintahan desa yang dapat dinilai dengan uang termasuk di dalamnya segala bentuk kekayaan yang berhubungan dengan hak dan kewajiban desa tersebut.

Landasan pemikiran dalam pengaturan mengenai desa adalah :

1. Keanekaragaman, yang memiliki makna bahwa istilah Desa dapat disesuaikan dengan asal-usul dan kondisi social budaya masyarakat setempat. Hal ini berarti pola penyelenggaraan pemerintahan serta pelaksanaan

\footnotetext{
${ }^{5}$ Undang-undang No.22 Tahun 1999 Tentang Pemerintahan Daerah
} 
pembangunan di desa harus menghormati sistem niali yang berlaku pada masyarakat setempat namun harus tetap mengindahkan sistem nilai bersama dalam kehidupan berbangsa dan bernegara.

2. Partisipasi, memiliki makna bahwa penyelenggaraan pemerintahan dan pembangunan desa harus mampu mewujudkan peran aktif masyarakat agar masyarakat senantiasa memiliki dan turut serta bertanggungjawab terhadap perkembangan kehidupan bersama sebagai sesame warga desa.

3. Otonomi asli, memiliki makna bahwa kewenangan pemerintahan desa dalam mengatur dan mengurus masyarakat setempat didasarkan pada hak asal usul dan nilai-nilai social budaya yang terdapat pada masyarakat setempat namun harus diselenggarakan dalam persepktif administrasi pemerintahan Negara yang selalu mengikuti perkembangan jaman.

4. Demokratisasi, memiliki makna bahwa penyelenggaraan pemerintahan dan pelaksanaan pembangunan di Desa harus mengakomodasi aspirasi masyarakat yang diartikulasi dan diagregasi melalui Badan Permusyawaratan Desa dan Lembaga Kemasyarakatan sebagai Mitra Pemerintahan Desa.

5. Pemberdayaan masyarakat, memiliki makna bahwa penyelenggara pemerintahan dan pelaksanaan pembangunan di Desa ditujukan untuk meningkatkan taraf hidup dan kesejahteraan masyarakat melalui penetapan kebijakan, program dan kegiatan yang sesuai dengan esensi masalah dan prioritas kebutuhan masyarakat. ${ }^{6}$

Berdasarkan Undang-undang No. 32 Tahun 2004, Desa atau yang disebut dengan nama lain, adalah kesatuann masyarakat hukum yang memiliki batas-batas wi-

\footnotetext{
${ }^{6}$ Ibid, hal 3-4
} 
layah yurisdiksi, berwenang untuk mengatur dan mengurus kepentingan masyarakat setempat berdasarkan asal-usul dan adat-istiadat setempat yang diakui dan/atau dibentuk dalam sistem pemerintahan nasional dan berada di Kabupaten/kota, sebagaimana yang dimaksud dalam Undang-Undang Dasar Negara Republik Indonesia Tahun 1945.

Pemerintahan Desa adalah penyelenggaraan urusan Pemerintahan oleh Pemerintahan Desa dan Badan Permusyawaratan Desa dalam mengatur dan mengurus kepentingan masyarakat setempat berdasarkan asal-usul dan adat istiadat setempat. Urusan pemerintahan yang menjadi kewenangan desa mencakup :

a. Urusan pemerintahan yang sudah ada berdasarkan hak asal-usul desa;

b. Urusan pemerintahan yang menjadi kewenangan kabupaten/kota yang diserahkan pengaturannya kepada desa;

c. Tugas pembantuan dari pemerintah, pemerintah provinsi, dan pemerintah kabupaten/kota, dan

d. Urusan pemerintahan lainnya yang oleh peraturan perundang-undangan diserahkan kepada desa ${ }^{7}$

Urusan pemerintahan yang akan diserahkan pengaturannya kepada desa berdasarkan Permendagri No. 30 Tahun 2006, harus didasarkan kepada hasil pengkajian dan evaluasi dengan pertimbangan aspek geografis, kemampuan personil, kemampuan keuangan, efesiensi dan efektivitas. Penyerahaan urusan pemerintahan tersebut ditetapkan dengan peraturan daerah kabupaten/kota, yang selanjtnya pemerintahan desa bersama BPD melakukan evaluasi untuk menetapkan urusan pemerintahan yang

\footnotetext{
${ }^{7}$ Pasal 7 Peraturan Pemerintah No. 72 Tahun 2005
} 
dapat dilaksanakan di desa, dan kesiapan pemerintahan desa ditetapkan dengan keputusan kepala desa atas persetujuan pimpinan BPD.

Berdasarkan keputusan kepala desa tersebut, bupati /walikota menetapkan peraturan bupati/walikota tentang penyerahan urusan pemerintahan kabupaten/kota kepada desa. Penyerahan tersebut dilaksanakan secara nyata dan serentak dan disaksikan oleh camat serta seluruh kepala badan/dinas/kantor.

Pemerintah kabupaten/kota dapat menambah penyerahan urusan pemerintahan kabupaten/kota kepada desa atas permintaan pemerintahan desa. Apabila pelaksanaan urusan pemerintahan yang telah diserahkan oleh kabupaten/kota kepada desa dalam kurun waktu 2 (dua) tahun tidak berjalan secara efektif, pemerintah kabupaten/kota dapat menarik sebagia atau seluruh urusan pemerintahan yang telah diserahkan. Tata cara penarikan atau peraturan tersebut sekurang-kurangnya memuat tentang yaitu :

a. Kreteria pelaksanaan urusan pemerintahan;

b. Mekanisme penambahan urusan pemerintahan;

c. Mekanisme penarikan urusan pemerintahan.

Pelaksanaan urusan pemerintah kabupaten/kota yang diserahkan kepada desa dibiayai dari anggaran pendapatan dan belanja daerah kabupaten/kota. Urusan pemerintaha kabupaten/kota yang dapat diserahkan pengaturannya kepada desa meliputi : bidang pertanian dan ketahanan pangan; bidang pertambangan dan energy serta sumber daya mineral; bidang kehutan dan perkembunan; bidang perindustrian dan perdagangan; bidang koperasi dan usaha kecil dan menengah; bidang penanaman modal; bidang tenaga kerja dan trasmigrasi; bidang kesehatan; bidang pendidikan dan kebudayaan; bidang social; bidang penataan ruang; bidang pemukiman/perumahan; bidang pekerjaan umum; bidang perhubungan; bidang lingkungan hidup; bidang 
politik dalam negeri dan administrasi public; bidang otonomi desa; bidang perimbangan keuangan; bidang tugas pembantuan; bidang pariwisata; bidang pertanahan; bidang kependudukan dan catatan sipil; bidang kesatuan bangsa dan perlindungan masyarakat, dan pemerintahan umum; bidang perencanaan; bidang penerangan/informasi dan komunikasi; bidang pemberdayaan perempuan dan perlindungan anak; bidang keluarga berencana dan keluarga sejahtera; bidang pemuda dan olahraga; bidang pemberdayaan masyarakat desa; bidang statistic; bidang arsip dan perpustakaan. ${ }^{8}$

Mengenai Keuangan desa pada dasarnya merupakan sub sistem dari keuangan Negara sebagaimanadiatur dalam Undang-undang No. 17 Tahun 2003 Tentang keuangan Negara. Dalam penjelasan undang-undang tersebut dinyatakan bahwa pendekatan yang digunakan dalam merumuskan keuangan Negara adalah dari sisi objek, subjek, proses, dan tujuan. Dari sisi objek, yang dimaksud dengan keuangan Negara meliputi semua hak dan kewajiban Negara yang dapat dinilai dengan uang, termasuk kebijakan dan kegiatan dalam bidang fiskal, moneter dan pengelolaan kekayaan Negara yang dipisahkan, segala sesuatu baik berupa uang, maupun berupa barang yang dapat dijadikan milik Negara berhubungan dengan pelaksanaan hak dan kewajiban tersebut.

Berdasarkan pengertian keuangan Negara dengan pendekatan, terlihat bahwa hak dan kewajiban Negara yang dapat dinilai dengan uang diperluas cakupannya, yaitu termasuk kebijakan dan kegiatan dalam bidang fiskal, moneter dan pengelolaan kekayaan Negara yang dipisahkan. Berpijak pada penjelasan tersebut, sebagai sub sistem dari keuangan Negara, keuangan desan adalah semua hak dan kewajiban desa

\footnotetext{
${ }^{8}$ Peraturan Menteri Dalam Negeri Nomor 30 Tahun 2006 Tentang Tata cara penyerahan urusan pemerintah Kabupaten/Kota Kepada Desa.
} 
yang dapat dinilai dengan uang serta segala sesuatu baik berupa uan maupun barang yang berhubungan dengan pelaksanaan hak dan kewajinan desa. ${ }^{9}$

\section{A. Ruang Lingkup Keuangan Desa}

Berdasarkan pengertian tersebut, maka ruang lingkup keuangan desa secara otomatis sejalan dengan hak atau kewenangan yang dimiliki desa sebagaimana diatur pada Bab III Pasal 33 dan 34 Peraturan Pemerintah Nomor 43 Tahun 2014 yaitu :

1. Kewenangan berdasarkan hak asal usul, paling sedikit terdiri atas;

2. Kewenangan local berskala desa, paling sedikit terdiri atas;

3. Kewenangan yang ditugaskan oleh pemerintah, pemerintah provinsi, pemerintah daerah kabupaten/kota;

4. Kewenangan lain yang ditugaskan oleh pemerintah, pemerintah provinsi, pemerintah kabupaten/kota sesuai dengan ketentuan peraturan perundangundangan.

Selanjutnya hak sebagaimana tercerminan dari kewenangan desa tersebut dapat dirinci sebagai berikut :

Kewenangan berdasarkan hak asal usul, paling sedikit terdiri atas :

1) Sistem organisasi masyarakat adat;

2) Pembinaan kelembagaan masyarakat;

3) Pembinaan lembaga hukum adat;

4) Pengelolaan tanah kas desa; dan

5) Pengembangan peran masyarakat desa.

Kewenangan local berskala desa, paling sedikit terdiri atas :

\footnotetext{
${ }^{9}$ Bab VIII, Bagian kesatu, pasal 71 (1) Undang-undang No. 6 Tahun 2014 Tentang Desa.
} 
1) Pengelolaan tambahan perahu ;

2) Pengelolaan pasar desa;

3) Pengelolaan tempat pemandian umum;

4) Pengelolaan jaringan irigasi;

5) Pengelolaan lingkungan permukiman masyarakat desa;

6) Pembinaan kesehatan masyarakat dan pengelolaan pos pelayanan terpadu;

7) Pengembangan dan pembinaan sanggar seni dan belajar;

8) Pengelolaan perpustakaan desa dan taman bacaan;

9) Pengelolaan embung desa;

10) Pengelolaan air mimun berskala desa;

11) Pembuatan jalan desa antar pemukiman ke wilayah pertanian.

Kewenangan yang ditugaskan oleh pemerintah, pemerintah daerah provinsi,pemeritahan kabupaten/kota, dan

Kewenangan lain yang ditugaskan oleh pemerintah, pemerintah provinsi,pemeritahan kabupaten/kota sesuai dengan ketentuan peraturan perundang-undangan. Dalam hubungan ini Menteri dapat menetapkan jenis kewenangan desa sesuai dengan situasi, kondisi dan kebutuhan yang bersifat local. $^{10}$

Pelaksanaan atas semua kewenangan tersebut memerlukan sejumlah uang/dana baik yang merupakan hasil pungutan desa berdasarkan peraturan desa, maupun dana yang berasal dari APBN, bantuan APBD provinsi, alokasi Dana Desa

${ }^{10}$ Bab III Pasal 33 dan 34 Peraturan Pemerintah Nomor 43 Tahun 2014 Peraturan Pelaksanaan Undang-Undang Nomor 6 Tahun 2014 Tentang Desa. 
yang bersumber dari APBD kabupaten/kota maupun bagi hasil pajak dari retribusi kabupaten/kota. Adapun ruang lingkup keuangan desa, meliputi :

a) Hak desa untuk melakukan pungutan berdasarkan peraturan desa;

b) Kewajiban desa untuk menyelenggarakan pemerintahan desa dan membayar tagihan pihak ketiga;

c) Penerimaan desa;

d) Pengeluaran desa;

e) Kekayaan desa yang dikelola sendiri atau oleh pihak lain berupa uang, surat berharga, piutang, barang, serta hak-hak lain yang dapat dinilai dengan uang termasuk kekayaan yang dipisahkan oleh Badan Usaha Milik Desa;

f) Kekayaan pihak lain yang dikuasai oleh pemerintah desa dalam rangka penyelenggaraan tugas pemerintahan dan/atau kepentingan umum.

\section{B. Ruang Lingkup berdasarkan sifat pengelolaannya}

Dilihat dari sifat pengelolaannya keuangan desa dapat dibagi menjadi keuangan desa yang sifat pengelolaannya dilakukan secara langsung yang berupa anggaran pendapatan dan belanja Desa (APBDesa) dan keuangan desa yang sifat pengelolannya dilakukan secara terpisah yang dilakukan oleh Badan Usaha Milik Desa (BUMDesa).

Pengelolaan keuangan desa yang dilakukan secara tidak langsung atau terpisah oleh BUMDesa dimaksudkan buka saja untuk menjadi motor penggerak roda-roda perekonomian desa tetapi juga dimaksudkan sebagai sumber pendapatan desa. Untuk itu pengelolaan keuanga desa ini harus ditangani secara professional, sehingga kedua maksud tersebut dapat dicapai. 


\section{Asas-asas Pengelolaan Keuangan Desa}

Untuk mencapai efektivitas dan efesiensi dalam pengelolaan keuangan desa diperlukan sejumlah asas atau prinsip yang harus dijadikan pedoman, asas atau prinsip-prinsip dimaksud adalah :

1. Asas kesatuan, yaitu asas atau prinsip yang menghendaki agar semua pendapatan dan belanja desa disajikan dalam kesatuan dokumen anggaran desa;

2. Asas universalitas, yaitu asas atau prinsip yang mengharuskan agar setiap transaksi keuangan desa ditampilkan secara utuh dalam dokumen anggaran desa;

3. Asas tahunan yaitu asas atau prinsip yang membatasi masa berlakunya anggaran untuk suatu tahun anggaran;

4. Asas spesialitas, yaitu asas atau prinsip yang mewajibkan agar setiap kredit anggaran yang disediakan terinci secara jelas peruntukannya;

5. Asas akuntabilitas yang berorientasi pada hasil yaitu asas atau prinsip yang menentukan bahwa setiap kegiatan pengelolaan keuang desa harus dapat dipertanggungjawabkan kepada masyarakat desa, sesuai dengan ketentuan perundang-undangan;

6. Asas proporsionalitas yaitu asas atau prinsip yang mengutamakan keseimbangan antara hak dan kewajiban dalam pengelolaan keuangan desa.

7. Asas profesionalitas yaitu asas atau prinsip yang mengutamakan keahlian berdasarkan kode etik dan ketentuan perundang-undangan yang berlaku;

8. Asas keterbukaan yaitu asas atau prinsip yang membuka diri terhadap hdak masyarakat untuk memperoleh informasi yang benar, jujur dan tidak 
diskriminatif tentang pengelolaan keuangan desa dengan tetap memperhatikan perlindungan terhadap hak pribadi dan golongan.

9. Asas pemeriksanaan keuangan oleh BPK yang bebas dan mandiri yaitu asas atau prinsip yang memebrikan kebebasan bagi BPK untuk melakukan pemeriksaan keuangan desa dengan tidak boleh dipengaruhi oleh siapapun;

10. Asas value for money yaitu asas atau prinsip yang menekankan bahwa dalam pengelolaan keuangan desa harus dilakukan secara ekonomis, efesien, dan efektif;

11. Asas kejujuran yatu asas atau prinsip yang menekankan bahwa dalam pengelolaan dana public (termasuk APBDesa) harus dipercayakan kepada aparat yang memiliki integritas dan kejujuran yang tinggi, sehingga potensi munculnya praktek korupsi, kolusi dan nepotisme dapat diminimalkan;

12. Asas pengendalian yaitu asas atau prinsip yang menghendaki dilakukannya monitoring terhadap penerimaan maupun pengeluaran anggaran pendapatan dan belanja desa, sehingga bila terjadi selisih dapat segera di cari penyebab timbulnya selisih tersebut;

13. Asas ketertiban dan ketaatan terhadap peraturan perundang-undangan, yaitu asas atau prinsip yang mengharuskan bahwa dalam pengelolaan keuangan desa wajib berpedoman kepada peraturan perundang-undangan yang b erlaku;

14. Asas bertanggungjawab, yaitu asas atau prinsip yang mewajibkan kepada penerima amanah atau penerima mandate untuk mempertanggungjawabkan pengelolaan dan pengendalian sumberdaya dan pelaksanaan kebijakan yang dipercayakan kepadanya dalam rangka pencapaian tujuan yang telah ditetapkan; 
15. Asas keadilan, yaitu asas atau prinsip yang menekankan perlunya keseimbangan distribusi kewenangan dan pendanaannya dan atau keseimbangan distribusi hak dan kewajiban berdasarkan pertimbangan objektif;

16. Asas kepatutan yaitu asas atau prinsip yang menekankan adanya suatu sikap dan tindakan yang wajar dan proporsional;

17. Asas manfaat untuk masyarakat, yaitu asas atau prinsip yang mengharuskan bahwa keuangan desa wajib digunakan atau diutamakan untuk memenuhi kebutuhan masyarakat desa.

Berbagai asas atau prinsip pengelolaan keuangan tersebut perlu dijadikan pedoman dalam mengelola keuangan desa, agar dana yang jumlahnya sangat terbatas itu dapat dipergunakan secara efektif, efisien, ekonomis dan berkedilan. Secara efektif maksudnya bahwa pengelolaan keuangan desa tersebut harus dapat mencapai tujuan atau sasaran yang ingin dicapai, secara efisien, maksudnya bahwa pengelolaan keuangan dimaksud dapat menghasilkan perbandingan terbaik anatara masukan dengan keluarnya.

Sedangkan secara ekonomis, maksudnya bahwa pengelolaan keuangan tersebut dapat menghasilkan perbandingan terbaik antara masukan dengan nilai masukan, adapun secara berkeadilan, maksudnya bahwa pengelolaan keuangan tersebut harus dapat memenuhi rasa keadilan dalam masyarakat. Sumber pendapatan desa dikelola melaui anggaran pendapatan dan belanja desa. Pengelolaan keuangan desa dilakukan oleh kepala desa yang dituangkan dalam peraturan desa tentang anggaran pendapatan dan belanja desa. Pedoman pengelolaan keuangan desa 
ditetapkan oleh bupati/walikota dengan berpedoman pada peraturan Menteri Dalam Negeri No. 37 Tahun 2007 tentang pedoman pengelolaan keuangan desa.

Pengertian keuangan desa menurut Undang-undang No. 32 Tahun 2004 pasal 212 ayat (1) jo' permendagri No. 37 Tahun 2007 Pasal 1 angka (1) bahwa keuangan desa adalah semua hak dan kewajiban dalam rangka penyelenggaraan pemerintahan desa yang dapat dinilai dengan uang termasuk di dalamnya segala bentik kekayaan yang berhubungan dengan hak dan kewajiban desa tersebut.

Sumber pendapatan desa menurut undang-undang No. 32 Tahun 2004 pasal 212 ayat (3) terdiri atas :

1. Pendapatan asli desa;

2. Bagi hasil pajak daerah dan retribusi daerah kabupaten/kota;

3. Bagian dari dana perimbangan keuangan pusat dan daerah yang di terima oleh pemerintah kabupaten/kota;

4. Bantuan dari pemerintah, pemerintah provinsi dan pemerintah kabupaten/kota.

5. Hibah dan sumbangan dari pihak ketiga.

Lebih lanjut mengenai keuangan desa diatur dalam Bab VII PP No. 72 Tahun 2005 yang dalam pasal 67 menetapkan bahwa :

1. Penyelenggaraan urusan pemerintahan desa yang menjadi kewenangan desa didanai dari anggaran pendapatan dan belanja desa, bantuan pemerintah dan bantuan pemerintahan daerah;

2. Penyelenggaraan urusan pemerintah daerah yang diselenggarakan oleh pemerintah desa didanai dari anggaran pendapatan dan belanja daerah;

3. Peneyelenggaraan urusan pemerintah yang diselenggarakan oleh pemerintah desa didanai anggaran pendapatan dan belanja Negara. 
Kemudian pasal 68 PP No. 72 Tahun 2005 menetapkan bahwa sumber pendapatan desa terdiri atas :

1. Pendapatan asli desa yang meliputi :

a. Hasil usaha desa;

b. Hasil kekayaan desa;

c. Hasil swadaya dan partisipasi;

d. Hasil gotong royong;

e. Lain-lain pendapatan asli yang sah.

2. Bagi hasil pajak daerah kabupaten/kota paling sedikit $10 \%$ (sepuluh per seratus) untuk desa dan dari retribusi kabupaten/kota sebagian di peruntukkan bagi desa;

Dari bagi hasil pajak daerah kabupaten/kota paling sedikit $10 \%$ (sepuluh per seratus) diberikan langsung kepada desa.

Dari retribusi kabupaten/kota sebagian diperuntukkan bagi desa yang dialokasikan secara propesional.

3. Bagian dari dana perimbangan keuangan pusat dan daerah yang diterima oleh kabupaten/kota untuk desa paling sedikit 10\% (sepuluh per seratus), yang pembagiannya untuk setiap desa secara proposional yang merupakan alokasi dana desa;

> Yang dimaksud dengan "bagian dari dana perimbangan keuangan pusat dan daerah" adalah terdiri dari dana bagi hasil pajak dan sumber daya alam ditambah dana alokasi umum setelah dikurangi belanja pegawai; 
Dana dari kabupaten/kota diberikan langsung kepada desa untuk dikelola oleh pemerintahan desa, dengan ketentuan 30\% (tiga puluh per seratus) digunakan untuk biaya operasional pemerintah desa dan BPD dan $70 \%$ (tujuh puluh per seratus) digunakan untuk kegiatan pemberdayaan masyarakat.

4. Bantuan keuangan dari pemerintah, pemerintah provinsi, dan pemerintah kabupaten/kota dalam rangka pelaksanaan urusan pemerintahan :

Bantuan dari pemerintahan diutamakan untuk tunjangan penghasilan kepala desa dan perangkat desa;

Bantuan dari provinsi dan kabupaten/kotadigunakan untuk percepatan atau akselerasi pembangunan desa.

5. Hibah dan sumbangan dari pihak ketiga yang tidak mengikat

Sumbangan adri pihak ketiga dapat berbentu hadiah, donasi, wakaf, dll. Sumbangan serta pemberian sumbangan dimaksud tidak mengurangi kewajiban pihak penyumbangan kepada desa;

Yang dimaksud dengan "wakaf" dalam ketentuan ini adalah perbuatan hukum wakaf untuk memisahkan dan/atau menyerahkan sebagian harta benda miliknya untuk dimanfaatkan selamanya atau jangka waktu tertentu sesuai dengan kepentingannya guna keperluan ibadah dan/atau kesejahteraan umum menurut syariah;

Sumbangan yang berbentuk barang, baik barang bergerak maupun barang tidak bergerak dicatat sebagai barang inventaris kekayaan milik desa sesuai dengan ketentuan peraturan perundang-undangan yang berlaku; 
Sumbangan yang berbentuk uang dicantumkan di dalam APBDesa.

\section{SIMPULAN}

Tata kelola penyelenggaraan pemerintahan yang baik dalam suatu Negara merupakan suatu kebutuhan yang tak terelakkan. Sejalan dengan dikeluarkan undangundang mengenai desa, perlu mendapatkan perhatian serius karena selama ini aturan mengenai desa di atura dalam undang-undang 32 tahun 2004 Tentang Pemerintahan Daerah. Diaturnya desa di dalam undang-undang tersendiri, memperlihatkan kemauan politik pemerintah untuk menjadikan desa sebagai basis pembangunan. Hal ini sejalan dengan visi dan misi undang-undang tersebut, dimana Negara melindung dan memberdayakan desa agar menjadi kuat, mandiri dan demokratis sehingga tercipta landasan yang kuat dalam melaksanakan penyelenggaraan pemerintahan, pembangunan dan kemasyarakata menuju terciptanya masyarakat yang adil makmur dan sejahteraan.

\section{DAFTAR PUSTAKA}

Abdur-rahman Olalekan Olayiwola. 2013. "Local Governance and Public Goods: Some Lessons from the British Local Government System”. European Journal of Bus iness and Social Sciences,Vol. 2, No.9, pp 39-66, December 2013. Available at http://www.ejbss.com/recent.aspx

Bambang Trisantono. 2010. Pedoman Penyelenggaraan pemerintahan desa. Jakarta. Fokusmedia

Chabib soleh, Heru Rochamansyah, 2010, Pengelolaan Keuangan desa, fokusmedia

Widjaja HAW. 2003. Pemerintahan Desa/marga . Jakarta PT. Raja Grafindo Persada. 
Undang-undang No.22 Tahun 1999 Tentang Pemerintahan Daerah Undang-undang no. 32 tahun 2004 Tentang Pemerintahan daerah

Peraturan Pemerintah No. 72 Tahun 2005 Tentang Desa

Peraturan Menteri Dalam Negeri Nomor 30 Tahun 2006 Tentang Tata cara penyerahan urusan pemerintah Kabupaten/Kota Kepada Desa.

Undang-undang No. 6 Tahun 2014 Tentang Desa, Bab VIII, Bagian kesatu, pasal 71

Peraturan Pemerintah Nomor 43 Tahun 2014 Peraturan Pelaksanaan Undang-Undang Nomor 6 Tahun 2014 Tentang Desa, Bab III Pasal 33 dan 34 